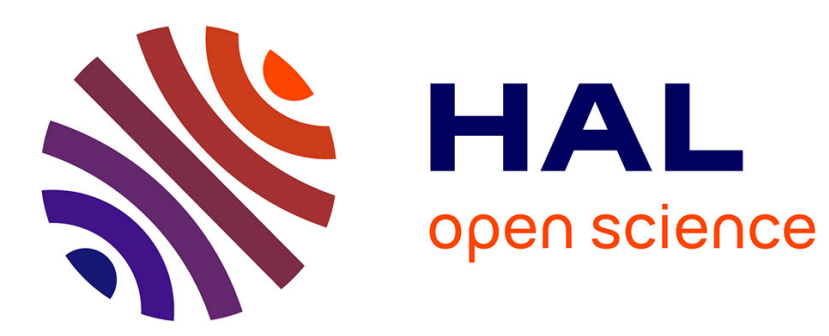

\title{
Evidence for carbon mobility in the amorphous alloy Fe81B 13.5Si3.5C2 from magnetic anisotropy measurements
}

\author{
W. Chambron, F. Lançon, A. Chamberod
}

\section{- To cite this version:}

W. Chambron, F. Lançon, A. Chamberod. Evidence for carbon mobility in the amorphous alloy Fe81B 13.5Si3.5C2 from magnetic anisotropy measurements. Journal de Physique Lettres, 1982, 43 (2), pp.55-57. 10.1051/jphyslet:0198200430205500 . jpa-00232007

\section{HAL Id: jpa-00232007 https://hal.science/jpa-00232007}

Submitted on 1 Jan 1982

HAL is a multi-disciplinary open access archive for the deposit and dissemination of scientific research documents, whether they are published or not. The documents may come from teaching and research institutions in France or abroad, or from public or private research centers.
L'archive ouverte pluridisciplinaire HAL, est destinée au dépôt et à la diffusion de documents scientifiques de niveau recherche, publiés ou non, émanant des établissements d'enseignement et de recherche français ou étrangers, des laboratoires publics ou privés. 
Classification

Physics Abstracts

$61.40 \mathrm{D}-66.30 \mathrm{~J}$

\title{
Evidence for carbon mobility in the amorphous alloy $\mathrm{Fe}_{81} \mathrm{~B}_{13.5} \mathrm{Si}_{3.5} \mathrm{C}_{2}$ from magnetic anisotropy measurements
}

\author{
W. Chambron, F. Lançon and A. Chamberod \\ Centre d'Etudes Nucléaires de Grenoble, Département de Recherche Fondamentale, \\ Section de Physique du Solide, 85 X, 38041 Grenoble Cedex, France
}

(Reçu le 25 septembre 1981, révisé le 2 novembre, accepté le 26 novembre 1981)

\begin{abstract}
Résumé. - L'alliage amorphe $\mathrm{Fe}_{81} \mathrm{~B}_{13,5} \mathrm{Si}_{3,5} \mathrm{C}_{2}$ présente, par rapport à l'alliage $\mathrm{Fe}_{81,5} \mathrm{~B}_{14,5} \mathrm{Si}_{4}$, une anisotropie magnétique induite supplémentaire, attribuée au réarrangement des atomes de carbone; ceux-ci migrent plus vite que les autres constituants, et par un mécanisme distinct, sans doute interstitiel. Leur mobilité est comparable à celle du carbone interstitiel dans les alliages cristallins fer-nickel de structure cfc.
\end{abstract}

\begin{abstract}
The amorphous alloy $\mathrm{Fe}_{81} \mathrm{~B}_{13.5} \mathrm{Si}_{3.5} \mathrm{C}_{2}$ shows an additional induced magnetic anisotropy, as compared with the alloy $\mathrm{Fe}_{81.5} \mathrm{~B}_{14.5} \mathrm{Si}_{4}$, attributed to a rearrangement of the carbon atoms. These atoms migrate faster than the other components, through a particular mechanism, probably interstitial in character. Their mobility is comparable to that of interstitial carbon in the crystalline iron-nickel alloys.
\end{abstract}

1. Introduction. - It is known that an induced magnetic anisotropy (IMA) can develop in ferromagnetic amorphous alloys, as a result of thermal treatment in a magnetic field, the so-called thermomagnetic treatment (TMT) [1-5]. This phenomenon results from short range atomic rearrangements, as in crystalline alloys [6]. Generally the IMA appears in only one step, although possibly with a broad spectrum of time constants [7-8]. We attempted to check whether only one step exists even when the alloy contains small atoms, such as carbon. Moreover, in crystalline materials, interstitial carbon atoms, are known to be much more mobile than other components.

2. Experiments. - We have studied the kinetics of the establishment of the IMA in the amorphous alloys $\mathrm{Fe}_{81} \mathrm{~B}_{13.5} \mathrm{Si}_{3.5} \mathrm{C}_{2}$ (Metglass 2605SC, purchased from Allied Chemical Corporation), and $\mathrm{Fe}_{81.5} \mathrm{~B}_{14.5} \mathrm{Si}_{4}$ (given by Dr. Luborsky from General Electric). Both alloys are melt spun and available as ribbons, 27 and $36 \mu \mathrm{m}$ thick respectively. Note that their composition differs only in the carbon concentration. For the sake of comparison, we have performed comparable experiments with a $\mathrm{Fe}_{20} \mathrm{Ni}_{80}$ crystalline alloy containing a small quantity of carbon $\left(760 \times 10^{-6}\right.$ at.). This alloy was made by melting iron and nickel with graphite in a HF furnace, in an atmosphere of helium. The ingot was then cold rolled to a thickness of $200 \mu \mathrm{m}$.

Samples are discs $(\varnothing 7 \mathrm{~mm})$ cut from the sheets. IMA is deduced from torque curves measured with an automatic torque magnetometer, at $30^{\circ} \mathrm{C}$. 
Before studying the IMA kinetics, the samples of amorphous alloys were annealed for $1 \mathrm{~h}$ at $400^{\circ} \mathrm{C}$, to achieve the structural relaxation, without crystallization : the crystallization temperatures are respectively $430{ }^{\circ} \mathrm{C}$ for the $\mathrm{Fe}_{81.5} \mathrm{~B}_{14.5} \mathrm{Si}_{4}$ alloy (deduced from the sharp IMA variation during an isochronal TMT $10^{\circ} \mathrm{C} / 10 \mathrm{~min}$.) and $480^{\circ} \mathrm{C}$ for the $\mathrm{Fe}_{81} \mathrm{~B}_{13.5} \mathrm{Si}_{3.5} \mathrm{C}_{2}$ alloy (as indicated by Allied Chemical Corporation for a heating rate $20^{\circ} \mathrm{C} / \mathrm{min}$.). The crystalline alloy was annealed for $1 \mathrm{~h}$ at $600^{\circ} \mathrm{C}$ to achieve the recrystallization after rolling.

The experimental method has been described elsewhere [7]. It consists of carrying out, successively, on the same sample :

a) A TMT of length $t_{0}$, at the temperature $T_{0}$, with a magnetic field applied along the direction $\varphi$ (angle between the magnetic field and some reference direction). Such a treatment induces an IMA corresponding to the torque :

$$
\begin{aligned}
\Gamma^{0} & =-K_{\mathrm{u}}^{0} \sin 2(\theta-\varphi) \\
& =A \sin 2 \theta+B \cos 2 \theta,
\end{aligned}
$$

with

$$
\begin{aligned}
& A=-K_{\mathrm{u}}^{0} \cos 2 \varphi, \\
& B=K_{\mathrm{u}}^{0} \sin 2 \varphi .
\end{aligned}
$$

$\theta$ is the angle between the magnetic field applied during the torque measurement, and the direction chosen as reference. $K_{\mathrm{u}}^{0}$ is the IMA energy density.

In our experiments, $\varphi=40^{\circ}, t_{0}=10 \mathrm{~min}$., $T_{0}=370^{\circ} \mathrm{C}$.

b) A series of isochronal TMT, with a magnetic field now along $\varphi=0$. It is clear that for such a field direction, the asymptotic value of the coefficients $A$ and $B$ is, from(2)

$$
\begin{aligned}
& A=-K_{\mathrm{u}}(T), \\
& B=0 .
\end{aligned}
$$

Therefore the asymptote value of $B$ is zero at all temperatures. Thus the kinetics of the IMA during step $(b)$ is characterized by the kinetics of $B$ going to zero.

Figure 1 shows the evolution of $B(T)$ during isochronal anneals $\left(10^{\circ} \mathrm{C} / 10 \mathrm{~min}\right.$.) for the two amorphous alloys and the crystalline alloy. Figure 2 gives the derivatives $d B / d T$. From these curves it appears that :

1) For the alloy $\mathrm{Fe}_{81.5} \mathrm{~B}_{14.5} \mathrm{Si}_{4}$ (curve $b$ ), the IMA develops in only one stage, as observed for other alloys [8].

2) For the alloy $\mathrm{Fe}_{81} \mathrm{~B}_{13.5} \mathrm{Si}_{3.5} \mathrm{C}_{2}$ (curve $a$ ), one observes the superimposition of two stages, one of which is practically identical with that of curve $b$, while the second occurs at a lower temperature $\left(160^{\circ} \mathrm{C}\right)$. The difference $(a-b)$ between curves $a$ and $b$ is also shown in figure 1 .

3) For the crystalline alloy (curve $c$ ), one observes only one stage at $160^{\circ} \mathrm{C}$, clearly narrower than the corresponding stage of curve $a$.

3. Discussion. - The IMA developed in the crystalline alloy results from a well-established mechanism [9], i.e. the rearrangement of carbon interstitial atoms, in the dissymmetrical environment formed by the $\mathrm{Fe}$ and $\mathrm{Ni}$ atoms, with respect to the direction of magnetization. The IMA density is proportional to the carbon concentration [9]. That property has been used to determine nondestructively the quantity of carbon in these alloys [10]. Also very good agreement has been found between the jump frequency as deduced from the experiments, and that calculated from the carbon diffusion coefficients [11]. The activation energy is $1.6 \mathrm{eV}$.

In bcc $\alpha$-iron, a similar phenomenon exists, studied mainly by magnetic after-effect measurements [12]. The activation energy is $0.76 \mathrm{eV}$ [13] and the peak for $\mathrm{dB} / \mathrm{d} T$ is about at $-30^{\circ} \mathrm{C}$. 


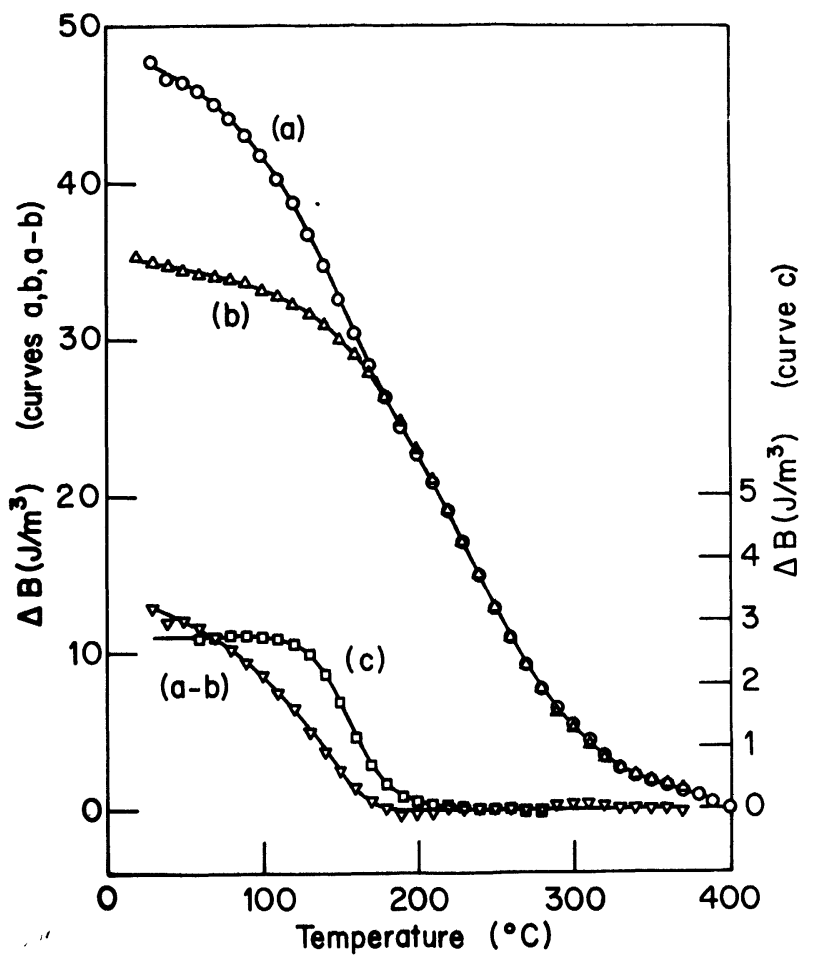

Fig. 1. - Variations of the anisotropy coefficient, $B$, during isochronal TMT, $10^{\circ} \mathrm{C} / 10 \mathrm{~min}$. : (a) $\mathrm{Fe}_{81} \mathrm{~B}_{13.5} \mathrm{Si}_{3.5} \mathrm{C}_{2}$ amorphous alloy. (b) $\mathrm{Fe}_{81.5} \mathrm{~B}_{14.5} \mathrm{Si}_{4}$ amorphous alloy. $(a-b)$ Difference between curves $(a)$ and $(b)$ (contribution of carbon atoms movements). (c) $\left(\mathrm{Fe}_{20} \mathrm{Ni}_{80}\right)_{1-x} \mathrm{C}_{x}$ crystalline alloy $\left(x=760 \times 10^{-6}\right.$ at. $)$.

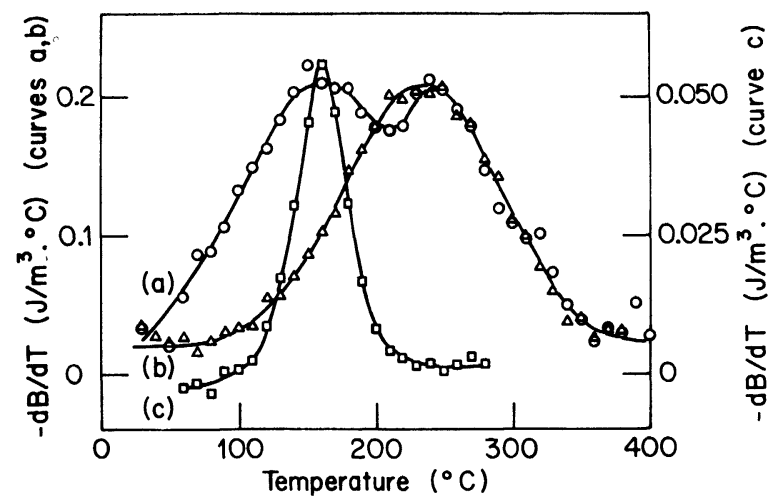

Fig. 2. - Derivatives of the curves of figure $1 ;(a),(b)$ and $(c)$ have the same meaning as in figure 1 .

In the two experiments just recorded, the magnetic anisotropy is induced by the rearrangement of interstitial atoms since the energy of an interstitial in a given site depends on the magnetization orientation. For instance, in the case of bcc iron, each octahedral site has a preferential direction $\langle 100\rangle$ which is that of the two iron next neighbours. Therefore the dissymmetry is in this case of " geometrical » origin. On the other hand, in the fcc iron-nickel alloy, the octahedral interstitial 
sites have a cubic symmetry, from a geometrical point of view; but, because there are two species of atom, the nature of the next neighbours of an interstitial introduces a dissymmetry [9], so-called " compositional " or "chemical ». In any case, whatever is the origin of the interaction energy with the magnetization, the IMA establishment time is considered to be roughly the inverse of the jump frequency of the interstitials.

In the case of amorphous alloys, curves $a$ and $b$ (Figs. 1-2) show that the introduction of carbon in the alloy, without noteworthy modification of the other components, induces a supplementary IMA, the kinetics of which is faster than that of the other atoms. Thus, carbon is thought to migrate by means of a mechanism different from that of the other components of the amorphous alloy, for instance an interstitial process. In this case, the anisotropy of a site appears clearly to originate from both the geometry and the nature of the neighbours.

From the experimental peak temperature, we deduce that the potential barrier to be crossed by the interstitials in order to migrate is comparable to that observed in the fcc alloys, and very different from that of the bcc iron. However, a large scattering of these barriers is to be noted (peak broadening) as compared with crystals.

A more detailed study of these phenomena, especially by means of isothermal TMT, is now in progress.

\section{References}

[1] Berry, B. S. and Pritchet, W. C., Phys. Rev. Lett. 34 (1975) 1022.

[2] Luborsky, F. E., BeCKer, J. J. and MCCARY, R. O., IEEE Trans. Magn. MAG-11 (1975) 1644.

[3] Luborsky, F. E. and WALTER, J. L., IEEE Trans. Magn. MAG-13 (1977) 953.

[4] Luborsky, F. E. and Walter, J. L., IEEE Trans. Magn. MAG-13 (1977) 1635.

[5] MiYazaki, T. and Takahashi, M., Japan J. Appl. Phys. 17 (1978) 1755.

[6] Ratheneau, G. W. and De Vries, G., in Magnetism and Metallurgy, edited by A. E. Berkowitz and

E. Kneller (Academic Press, New-York) 1969.

[7] Chambron, W. and Chamberod, A., Solid State Commun. 33 (1980) 157.

[8] Chambron, W. and Chamberod, A., Proceedings of the 7th International Conference on Internal Friction and Ultrasonic Attenuation in Solids, 6-9 July 1981, to be published in J. Physique Colloq., France.

[9] Adler, E. and Radeloff, C., J. Appl. Phys. 40 (1969) 1526.

[10] Caplain, A. and Chambron, W., Phys. Status Solidi (a) 52 (1979) 299.

[11] Caplain, A., Thesis, Grenoble, France (1978).

[12] Brissonneau, P., J. Phys. Chem. Solids 7 (1958) 22.

[13] Anagnostopoulos, T., Thesis, Grenoble, France (1968). 